\title{
HUBUNGAN DAYA LEDAK OTOT TUNGKAI DENGAN KEMAMPUAN SHOOTING PEMAIN CLUB FUTSAL SEKOLAH MENENGAH KEJURUAN NUSATAMA PADANG
}

\section{Oleh \\ Rosmawati ${ }^{1)}$ \\ Fakultas Ilmu Keolahragaan Universitas Negeri Padang}

Masalah dalam penelitian ini adalah kurangnya prestasi yang diperoleh oleh club futsal SMK NUSATAMA Padang. Penelitian ini bertujuan untuk mengetahui apakah terdapat hubungan daya ledak otot tungkai dengan kemampuan shootingpemain club futsal SMK NUSATAMA Padang. Jenis penelitian ini adalah korelasi. Populasi dalam penelitian ini yaitu semua pemain club futsal SMK NUSATAMA Padang. Teknik penarikan sampel adalah sampel jenuh. Penelitian ini dilaksanakan pada bulan Mei 2016. Instrumen penelitian dilakuakn dengan standing broad jump dan shooting. Pengujian data dianalisis menggunakan korelasi product moment. Hasil analisis korelasi $r_{x y}=0,25$ dengan pengujian signifikan koefisien korelasi . Hasil penelitian diperoleh terdapat hubungan daya ledak otot tungkai terhadap kemampuan shooting, hal ini ditandai dengan hasil yang diperoleh $t_{\text {hitung }} 1<$ $t_{\text {tabel }} 1,753$ yang menyatakan Ho diterima.

Kata Kunci: Daya Ledak Otot Lengan, Kemampuan Shooting

PENDAHULUAN

Olahraga pada saat sekarang ini dapat dikatakan sebagai suatu kebutuhan yang merupakan kegiatan yang dilakukan manusia yang ingin sehat baik jasmani maupun rohaninya. Dengan melakukan aktifitas seseorang dapat menjaga kestabilan kondisi tubuh agar tetap bersemangat dalam mengerjakan aktifitas sehari-hari. Bagi seorang atlet, untuk meraih atau mencapai target tersebut diperlukan usaha melalui perencanaan dan pelaksanaan yang terarah, terkoordinir dangan penyediaan sarana dan prasarana yang memadai. Melalui

kegiatan olahraga, kita mencoba untuk menciptakan suatu penampilan sikap baru dari seluruh bangsa Indonesia dalam mengisi pembangunan bangsa ini.

Dalam UU.RI No 3 Tahun 2005

Tentang Sistem Keolahragaan Nasional

BAB II pasal 4 telah digariskan :

"Keolahragaan Nasional
bertujuan memelihara dan
meningkatkan kesehatan dan
kebugaran, prestasi, kualitas
manusia, menanamkan nilai
moral dan akhlak manusia,
sportivitas, disiplin, mempererat
dan membina persatuan dan
kesatuan bangsa, memperkukuh
ketahanan nasional serta
mengangkat harkat martabat dan
kehormatan bangsa"


Berdasarkan kutipan diatas, jelas bahwa olahraga dapat memberikan sumbangan yang sangat berarti dan berharga bagi manusia secara menyeluruh, karena yang berkembang bukan hanya aspek kelenturan dan kebugaran jasmani saja, namun juga aspek lain yang sangat penting dari sosok manusia seutuhnya yaitu perkembangan pengetahuan penalaran, perkembangan intelegensi emosional dan sifat-sifat lainya yang membuat karakter seseorang menjadi tangguh, sportif dan disiplin.

Olahraga juga dilakukan untuk tujuan mencapai tingkat kesegaran jasmani tertentu. Dalam hal ini mulai dari berbagai bidang ilmu pengetahuan yang ada kaitannya dengan manusia seperti, pengetahuan dokter, sosial, ekonomi, lingkungan hidup dan lain-lain, yang diperhitungkan dan diperhatikan, dikerjakan dengan formal, baik program, sarana maupun fasilitasnya di bawah asuhan tenaga professional. Di dalam hal ini ilmu pembinaan dan pengembangan olahraga merupakan bagian dari upaya meningkatkan kesehatan jasmani dan rohani seluruh masyarakat, pemupukan watak disiplin, sportifitas serta pengembangan prestasi olahraga yang dapat membangkitkan kebanggaan nasional. Lepas dari hal tersebut yang tidak kalah pentingnya bahwa olahraga merupakan aspek kehidupan sehari-hari sehingga menjadi sesuatu yang dibutuhkan di kalangan masyarakat, baik kaum tua maupun muda.

Dalam pencapaian prestasi yang tinggi ada dua faktor yang mempengaruhi atlet, seperti yang diungkapkan oleh Syafruddin (1999:22), ada dua faktor yang mempengaruhi dalam pencapaian prestasi yaitu faktor internal dan faktor eksternal. Faktor internal meliputi kemampuan fisik, teknik, mental atlet, taktik, gizi dan makanan sebagainya. Sedangkan faktor eksternal merupakan pengaruh yang timbul dari luar diri atlet sendiri seperti keluarga, pelatih, sarana dan prasarana. Untuk mendapatkan keterampilan yang mumpuni, atlet tentu harus memiliki kebugaran fisik yang mumpuni pula, sebagaimana yang dikatakan Irianto (2004:3), kebugaran motoris yaitu kemampuan seseorang bekerja secara efisien yang menuntut keterampilan khusus. Jadi berdasarkan kata-kata diatas dapat disimpulkan bahwa kemampuan tubuh atau kebugaran adalah kemampuan dasar yang dimiliki seseorang untuk memperoleh suatu keterampilan dalam 
suatu cabang olahraga baik itu olahraga spesialisasi maupun olahraga rekreasi.

Peranan kondisi fisik dalam melakukan suatu keterampilan olahraga sangat penting. Hal tersebut sesuai dengan pendapat Harsono (1998). Kondisi fisik yang baik maka akan menghasilkan : 1). Peningkatan kemampuan sistem sirkulasi dan kerja jantung, 2). Peningkatan kekuatan, daya tahan dan kemampuan kondisi fisik lainnya, 3). Ekonomis gerakan yang lebih pada tujuan latihan, 4). Pemulihan yang lebih cepat dalam organ-organ tubuh setelah latihan, 5). Respon yang cepat dari organisme tubuh.

Terlepas dari pengembangan organisasi keolahragaan dan wadahwadah pembinaan lainnya, berolahraga secara teratur merupakan cara terbaik agar tubuh kita selalu dalam kondisi bugar dan sehat. Olahraga juga akan meningkatkan kecerdasan berfikir. Banyak sekali macam olahraga baik olahraga spesialisasi maupun rekreasi, yang dapat dilakukan untuk menjaga kesegaran jasmani seseorang, salah satunya yaitu bermain futsal.

Seperti yang telah dikemukakan sebelumnya, untuk meraih prestasi dalam olahraga dapat dipengaruhi oleh banyak faktor, salah satunya adalah teknik atau keterampilan. Keterampilan atau teknik merupakan suatu hal yang sangat penting bagi seorang untuk bermain futsal. Ariesbowo (2007:20), mengemukakan bahwa : Keterampilan dasar yang harus dimiliki pemain yaitu: 1). Teknik menjaga kebugaran tubuh, 2). Teknik penguasaan bola, 3). Teknik menendang, 4). Teknik menangkap bola untuk goalkeeping. Berdasarkan kutipan diatas jelaslah bahwa keterampilan dasar merupakan suatu hal yang penting bagi seseorang untuk bermian futsal. Dari sekian banyak bentuk teknik atau keterampilan dasar dalam permainan futsal, keterampilan menendang atau shooting adalah salah satu teknik dasar yang harus dimiliki oleh pemain futsal, untuk menciptakan gol ke gawang lawan dalam suatu pertandingan. Karena sesuai dengan tujuan permainan futsal yaitu memasukkan bola ke gawang lawan sebanyak-banyaknya (Feri Kurniawan 2011:104).

Kemampuan melakukan shooting bukan hanya untuk pemain depan saja, tetapi sebaiknya keseluruhan pemain memiliki keterampilan untuk melakukan shooting dalam setiap kesempatan yang diperolehnya. Pelaksanaan shooting disini bukan hanya sekedar melakukan shooting saja, tetapi shooting yang dimaksud disini kemampuan 
mengarahkan bola masuk ke mulut gawang dalam melaksanakan shooting. Sehingga arah shooting yang dilakukan dapat menghasilkan gol sebagaimana tujuan dari permainan futsal yang hampir sama dengan sepak bola.

Kekuatan dapat diartikan sebagai kemampuan sekelompok otot melawan beban dalam satu usaha, Irianto (2004:35). Kutipan ini berbanding lurus dengan pelaksanaan shooting, karena shooting akan lebih baik pelaksannaannya apabila diiringi dengan kekuatan dan arah shooting yang baik pula. Dalam melakukan shooting daya ledak otot tungkai sangat dibutuhkan, karena di dalam daya ledak otot tungkai terdapat unsur kekuatan.

Permaianan futsal terus mengalami perubahan dan perkembangan baik dari segi peraturan, teknologi dan fasilitas yang menyangkut lancarnya jalan pertandingan. Yang tidak kalah pentingnya sekarang ini terus dikembangkan dan ditingkatkan adalah teknik, taktik dan strategi yang diterapkan para pemain maupun pelatih dalam menghadapi suatu pertandingan. Semua itu ditujukan agar permainan futsal ini lebih indah dan menarik. Menjadi pemain futsal yang baik, harus mengetahui terlebih dahulu teknik dalam permainan futsal yaitu teknik foundation atau teknik dasar, layaknya seseorang membangun rumah, semakin kuat pondasinya maka semakin kokoh bangunannya dan semakin banyak variasi, bentuk serta ukuran yang didirikan, jadi keterampilan dasar yang seperti itulah yang dibutuhkan oleh para pemain.

Berdasarkan pengamatan awal penulis dilapangan pada saat latihan dan main game sesama pemain club, para pemain club futsal SMK NUSATAMA Padang kurang maksimal dalam melakukan shooting ke gawang lawan dimana banyak shooting-shooting yang dilakukan tidak tepat pada sasaran yang diinginkan atau dengan kata lain tidak menghasilkan gol. Seperti bola yang melambung diatas mistar, melenceng ke samping tiang gawang, tendangan yang lemah seakan tidak memiliki kekuatan sehingga mudah ditangkap penjaga gawang. Apabila hal ini terus dibiarkan maka akan sulit tercapai prestasi sesuai yang diinginkan, karena tidak adanya peningkatan. Oleh sebab itu perlu dilakukan penelitian tentang faktor yang terkait dengan kemampuan shooting seperti perkenaan kaki tendang terhadap bola, letak kaki tumpu, power otot tungkai, koordinasi gerakan dalam sepak bola, pengaruh lapangan atau 
sarana dan prasarana. Sehingga dari hasil penelitian tersebut bisa ditarik kesimpulan sebagai antisipatif dan korektif bagi kemajuan perkembangan pemain club futsal SMK NUSATAMA Padang pada masa-masa yang akan datang.

\section{METODE}

Jenis penelitian ini adalah penelitian korelasional yang ingin melihat hubungan antara variabel bebas dan variabel terikat. Adapun variabel bebasnya adalah daya ledak dan variabel terikatnya kemampuan shooting ke gawang. Penelitian ini dilaksanakan di lapangan terbuka SMK NUSATAMA Padang dan waktu pengambilan data pada bulan April 2016 sampai bulan Mei 2016.

Menurut Dwi Priyatno (2008:9), populasi adalah suatu kelompok atau sekumpulan subjek atau objek yang akan dikenai generalisasi penelitian. Apabila seseorang ingin meneliti semua elemen yang ada diwilayah penelitian, maka penelitianya merupakan penelitian populasi. Studi atau penelititannya juga disebut studi populasi atau studi sensus. Populasi dalam penelitian ini adalah semua siswa laki-laki yang sekolah di SMK NUSATAMA Padang yang terdaftar sebagai pemain club futsal
SMK NUSATAMA Padang berjumlah 17 orang.

Menurut Sugiyono (2001:61) sampling jenuh adalah teknik pengambilan sampel bila semua anggota populasi digunakan sebagai sampel. Hal ini sering dilakukan bila jumlah populasi relatif kecil, kurang dari 30 orang. Istilah lain dari sampel jenuh adalah sensus, dimana semua anggota populasi dijadikan sampel.

Teknik pengambilan data yang dilakukan dalam penelitian ini yang pertama adalah tes daya ledak otot tungkai yang dilakukan di bak pasir lompat jauh dengan menggunakan alat ukur berupa meteran, yang kedua adalah tes shotting ke gawang, dengan teknik analisis data adalah korelasi sederhana (product moment). Sesuai dengan metodologi penelitian, dalam pengambilan data dipergunakan dua macam instrument tes yaitu : (a) Standing Broad Jump atau lebih dikenal dengan lompat jauh tanpa awalan, (b) Shooting ke gawang untuk mengambil kemampuan shooting ke gawang.

Untuk pengukuran daya ledak otot tungkai dalam penelitian ini dipakai alat ukurnya yaitu lompat jauh tanpa awalan atau disebut juga dengan istilah Standing Broad Jump dengan satuan meteran. Ini sudah sesuai dengan apa 
yang dikatakan dalam Arsil (1999:80) yang mengatakan untuk menentukan kemampuan daya ledak terutama untuk anggota gerak bawah dapat dilakukan dengan lompat jauh tanpa awalan atau tes Standing Broad Jump dilaksanakan dalam bak pasir, sehingga memudahkan dalam pengukuran karena akan meniggalkan jejak setelah mendarat di pasir.

Pelaksanaan tes shooting ini dinamakan tes sepak sasaran. Dikeluarkan oleh Departemen Pendidikan dan Kebudayaan pusat kesegaran jasmani dan rekreasi (1984) untuk permaianan sepakbola, karena pada dasarnya permainan sepak bola hampir sama dengan permainan futsal maka peneliti berasumsi tes ini dapat digunakan pada tes shooting futsal, dengan beberapa peraturan yang dimodifikasi. Dengan pelaksanaan sebagai berikut : "Testee mendapat kesempatan enam kali menendang perorang dengan dua kali kesempatan, yang dilaksanakan disetiap tempat yang telah ditetapkan, yaitu tiga tempat untuk melakukan tembakan ke gawang. Apabila testee sudah siap untuk melakukan shooting, tanpa aba-aba testee mengiring bola ke depan dan sebelum melewati garis batas testee langsung menendang bola tersebut".
Data yang diperoleh diolah dengan teknik analisis korelasi product moment. Hal ini sesuai dengan jenis penelitian yang peneliti lakukan. Sebelum data diolah, terlebih dahulu dilakukan uji normalitas, yang bertujuan untuk melihat apakah data yang diperoleh dari hasil tes daya ledak otot tungkai dan kemampuan shooting ke gawang pemain club futsal SMK NUSATAMA Padang berdistribusi normal. Setelah data yang diperoleh berdistribusi normal, maka dipakai korelasi product moment dari Pearson dalam Suharsimi Arikunto (2008:72), dengan rumus sebagai berikut : $r x y=$

$$
\frac{N \sum X Y-\left(\sum X\right)\left(\sum Y\right)}{\left.\left.\sqrt{\left\{N \sum X^{2}\right.}-\left(\sum X\right)^{2}\right\} N \sum Y^{2}-\left(\sum Y\right)^{2}\right\}}
$$

Uji signifikan korelasi, untuk mengetahui apakah yang telah di hitung melalui koefisien itu signifikan atau tidak, maka perlu dilakukan langkah mencari uji signifikan korelasi oleh Pearson dalam Dwi Prayitno (2008:57) dengan rumus :

$\mathrm{t}=\frac{\boldsymbol{r} \sqrt{n-2}}{\sqrt{1-r^{2}}}$

Dengan kriteria pengujian sebagai berikut :

$t(\mathrm{I}-1 / 2 \alpha)<t(\mathrm{I}-1 / 2 \alpha)$ 
Keterangan :

rxy $=$ Koefisien korelasi antara $x$ dan $y$

$\sum \boldsymbol{x}=$ Jumlah data $x$ (daya ledak otot tungkai )

$\sum \mathbf{y}=$ Jumlah data $y$ (kemampuan shooting )

$\mathrm{x}^{2}=$ Jumlah data $\mathrm{x}^{2}$

$$
\begin{array}{ll}
\sum \mathbf{y}^{\mathbf{2}} & =\text { Jumlah data } \mathrm{y}^{2} \\
\mathrm{n} & =\text { Jumlah sample } \\
\mathrm{r} & =\text { Korelasi } \\
\mathrm{t} & =\text { Signifikan }
\end{array}
$$

\section{HASIL DAN PEMBAHASAN}

\section{Daya Ledak Otot Tungkai}

Analisis deskriptif daya ledak otot tungkai responden penelitian, diperoleh rerata hitung (mean) $=1.94$ standar deviasi $=0.108$ nilai minimum $=1.75$ dan maksimum = 2.12.

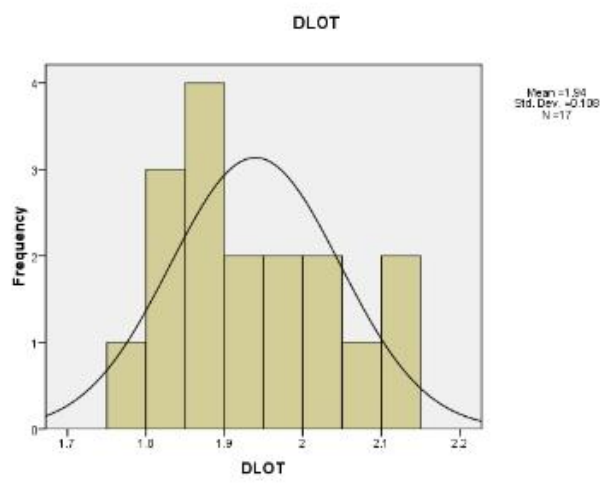

Gambar 1. Histogram Data Daya Ledak Otot Tungkai

\section{Kemampuan Shooting}

Analisis deskriptif kemampuan shooting responden penelitian, diperoleh rerata hitung (mean) = 9.29 standar deviasi $=2.173$ nilai minimum $=6$ dan maksimum $=14$.

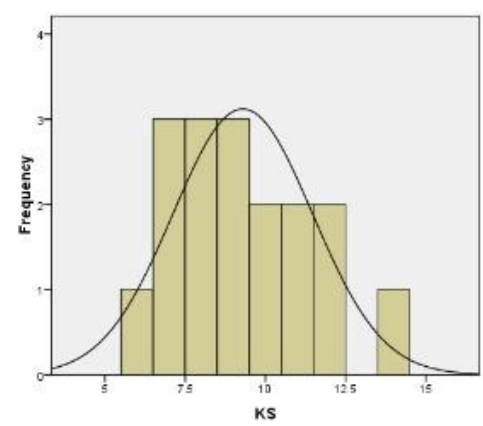



\section{Gambar 5.Histogram Data Kemampuan Shooting}

\section{PEMBAHASAN}

Hasil analisis menunjukan bahwa daya ledak otot tungkai (X) memiliki hubungan yang signifikan serta memberikan kontribusi yang berarti terhadap kemampuan shotting ( $Y$ ), data penelitian dapat dibaca bahwa hubungan (kolerasi) daya ledak otot tungkai dan kemampuan shooting bernilai1 $t_{\text {hitung }}<1.753 t_{\text {tabel }}$. Dengan demikian dapat disimpulkan hipotesis kerja yang diajukan (Ho) diterima.

Dari hasil analisis data menunjukkan bahwa daya ledak otot tungkai memiliki hubungan yang signifikan serta memberikan kontribusi yang berarti terhadap kemampuan shotting pemain club futsal Sekolah Menengah NUSATAMA Padang. Perhitungan korelasi antara daya ledak otot tungkai (x) terhadap hasil kemampuan shotting (y). Menurut Aryadie Adnan (2015:27) Kriteria

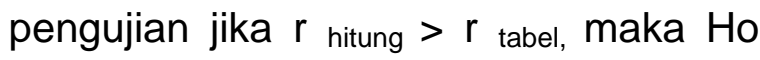


menyatakan tidak terdapat hubungan antara variabel (ditolak) dan apabila $r$ hitung $<r$ tabel maka Ho diterima menyatakan terdapat hubungan yang signifikan.

Hal ini sejalan dengan hipotesis yang di ajukan yang mana hipotesis menyatakan bahwa adanya hubungan yang berarti antara daya ledak otot tungkai terhadap kemampuan shotting pemain club futsal Sekolah Menengah Kejuruan NUSATAMA Padang. Menurut Suharsimi Arikunto (2006:75) bahwa perumusan hipotesis dilakukan secara hati - hati setelah peneliti memperoleh bahan yang lengkap berdasarkan landasan teori yang kuat. Namun demikian rumusan hipotesis tidak selamanya benar. Benar atau tidaknya hipotesis tidak ada hubunganya dengan terbukti dan tidaknya hipotesis tersebut. Mungkin seorang peneliti merumuskan hipotesis yang isinya benar, tetapi setelah datanya terkumpul dan dianalisis ternyata bahwa hipotesis tersebut ditolak, atau tidak terbukti. Sebaliknya mungkin seorang peneliti merumuskan sebuah hipotesis yang salah, tetapi setelah dicocokkan dengan datanya, hipotesis yang salah tersebut terbukti.
Berdasarkan hasil dari penelitian yang telah diuraikan pada bab terdahulu, dapat dikemukakan kesimpulan bahwa hasil yang diperoleh dari daya ledak otot tungkai terdapat hubungan yang signifikan dengan kemampuan shooting, hal ini ditandai dengan hasil yang di peroleh $t_{\text {hitung }} 1<t_{\text {tabel }}$ 1,753 .

\section{DAFTAR RUJUKAN}

Adnan, Aryadie Dkk (2015). Silabus Dan Handout Mata Kuliah Statistik 2. FIK : UNP Padang

Ariesbowo, (2007). Menjadi Pemain Futsal Hebat. Jakarta : Be Champion

Arsil, (1999). Pentingnya latihan kondisi untuk meningkatkan prestasi pemain sepakbola, Makalah. Padang : FPOK IKIP Padang

Diknas (DEPDIKBUD ), (1984 ). Paket Penelitian Kesegaran Jasmani dan Rekreasi di Pusdiklat olahraga pelajara khusus sepakbola : DEPDIKBUD

Priyatno, Dwi (2008). Mandiri Belajar (Statistical Product and Service Solution) untuk Analisis \& Uji Statistik. Yogyakarta : Mediakom

Harsono, (1998 ). Coaching dan Aspekaspek Coaching. Jakarta : DEPDIKBUD

Irianto, (2004). Pedoman Praktis Berolahraga untuk Kebugaran dan Kesehatan. Yogyakarta : ANDI

Justinus dkk, (2008). Inspirasi dan Spirit FUTSAL. Jakarta : Raih Asa Sukses

\section{KESIMPULAN}


Kurniawan, Feri (2011). Buku Pintar Olahraga. Jakarta : Laskar Aksara

Rahmani, Mikanda (2014). Buku Super Lengkap Olahraga. CipayungJakarta Timur : Dunia Cerdas

Ratinus, (1999 ). Sepakbola. Padang. FIK : UNP Padang

Sanjaya, Santi (2015). Pengaruh Industri Rumah Tangga Sapu Lidi Sebagai Kerja Sampingan Ibu Rumah Tangga Terhadap Tingkat Pendapatan Keluarga Di Korong Kasai Kecamatan Batang Anai Kabupaten Padang Pariaman. Skripsi PIPS-STKIP Padang.

Sugiyono, (2001). Statistika Untuk Penelitian. Bandung : Alfabeta

Suharsimi, Arikunto (2008). Dasar-dasar Evaluasi Pendidikan. Jakarta : Bumi Aksara

(2006). Dasardasar Evaluasi Pendidikan. Jakarta : Bumi Aksara

Syafruddin, (1999). Dasar-Dasar Kepelatihan Olahraga. FIK : UNP Padang

Syahara, Sayuti (1994). Pengaruh Perbedaan Latihan Boundrup Jump dengan Latihan Box Driil terhadap Kemampuan Daya Ledak Otot Tungkai. (Laporan penelitian). Padang : IKIP Padang

Zalfendi dkk, (2010). Sepakbola. Padang : SUKABINA 